\title{
Palladium-Catalyzed Nucleophilic Allylation of Aldehydes or Aldimines
}

Metal-Catalyzed Asymmetric

Synthesis and Stereoselective Reactions

\section{Key words}

allylation

vinylcyclopropanes

palladium

Selected examples:

$\mathrm{R}^{1} \mathrm{CHO}$ (1 equiv), $\mathrm{Et}_{2} \mathrm{Zn}$ (2.4 equiv)

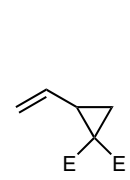
$\mathrm{Pd}(\mathrm{acac})_{2}(5 \mathrm{~mol} \%), \mathrm{Ph}_{3} \mathrm{P}(10 \mathrm{~mol} \%)$ $(1.2$ equiv)
$\mathrm{E}=\mathrm{CO}_{2} \mathrm{Me}$<smiles>C=CC(O)CC(C)C(F)F</smiles><smiles>C=CC1CC(C)C(=O)OC1C</smiles><smiles>CC1(c2ccccc2)CC1</smiles>

Significance: Ring-expansion reactions of vinylcyclopropanes are powerful tools for organic synthesis. The authors describe the palladiumcatalyzed nucleophilic allylation of aldehyde and aldimines with vinylcyclopropane in the presence of dimethylzinc.
SYNFACTS Contributors: Hisashi Yamamoto, Atsuto Izumiseki Synfacts 2015, 11(1), 0043 Published online: 15.12.2014 Dol: 10.1055/s-0034-1379748; Reg-No.: H15414SF
Comment: The allylation of aldehydes with vinylcyclopropane and diethylzinc proceeded to provide homoallyl alcohols with anti stereoselectivity. Aldimines prepared from aldehyde and primary amines in situ underwent a similar allylation to give homoallylamines with syn stereoselectivity. The products can be converted by reaction with a tetranuclear zinc cluster into $\gamma$-vinyl- $\delta$-valerolactons and $\gamma$-vinyl- $\delta$-valerolactams. The transformation is useful for the efficient synthesis of bioactive molecules. 